\title{
The Global Supply Chain of Sexual Exploitation and the Necessity of Combating the Demand for Commercial Sex
}

Lisa L. Thompson

National Center on Sexual Exploitation, lisa@ncose.com

Follow this and additional works at: https://digitalcommons.uri.edu/dignity

Part of the Civic and Community Engagement Commons, Community-Based Learning Commons, Community-Based Research Commons, Criminology Commons, Family, Life Course, and Society Commons, Gender and Sexuality Commons, Inequality and Stratification Commons, International and Area Studies Commons, Legal Studies Commons, Politics and Social Change Commons, Psychology Commons, Social Control, Law, Crime, and Deviance Commons, Social Psychology and Interaction Commons, and the Social Work Commons

\section{Recommended Citation}

Thompson, Lisa L. (2017) "The Global Supply Chain of Sexual Exploitation and the Necessity of Combating the Demand for Commercial Sex," Dignity: A Journal of Analysis of Exploitation and Violence: Vol. 2: Iss. 3, Article 8. https://doi.org/10.23860/dignity.2017.02.03.08

This Freedom from Sexploitation: An Agenda is brought to you for free and open access by DigitalCommons@URI. It has been accepted for inclusion in Dignity: A Journal of Analysis of Exploitation and Violence by an authorized editor of DigitalCommons@URI. For more information, please contact digitalcommons-group@uri.edu. 


\section{The Global Supply Chain of Sexual Exploitation and the Necessity of Combating the Demand for Commercial Sex}

\section{Keywords}

sexual exploitation, sex buyers, male consumers, sex trade, female consumers, prostitution, sex work, "voluntary prostitution, " "forced prostitution, " abolitionist, global supply chain, "the demand, " law

\section{Creative Commons License}

\section{(c) (1) $(9)$}

This work is licensed under a Creative Commons Attribution-Noncommercial-No Derivative Works 4.0 License. 
DIGNITY

Volume 2, Issue 3, Article 8, 2017
A JOURNAL ON

SEXUAL EXPLOITATION

AND VIOLENCE

\title{
THE GLOBAL SUPPLY CHAIN OF SEXUAL EXPLOITATION AND THE NECESSITY OF COMBATING THE DEMAND FOR COMMERCIAL SEX
}

\author{
Lisa L. Thompson
}

Vice President of Education and Outreach, National Center on Sexual Exploitation

\section{KEYWORDS}

sexual exploitation, sex buyers, male consumers, sex trade, female consumers, prostitution, sex work, "voluntary prostitution," "forced prostitution," abolitionist, global supply chain, "the demand," law

"To treat prostitution as if it is not sexual exploitation is to assume that sexual dehumanization is the original human condition." 1

7 HE SEX TRADE is a market principally for male consumption of female "sexual services." There are, of course, prostitution markets for male consumption of male-and transgendered-provided sexual sex acts, as well as female consumers of male-and female-provided sex acts. ${ }^{2}$ Nevertheless, as researchers have explained:

The most obvious generalization that can be made is that in all societies and periods that have been examined, institutionalized prostitution has been aimed at a male clientele and the overwhelming majority of prostitutes have been women. Though male prostitutes have existed in many societies, they have primarily served other males whose sexual preference was males or who turned to fellow males in special circumstances where there was a lack of contact with women. Only occasionally has the male prostitute who serviced a female clientele been mentioned in literature; to

\footnotetext{
${ }^{1}$ Kathleen Barry, The Prostitution of Sexuality (New York, NY: New York University Press, 1995), 71.

2 Jennifer Cunningham, "Sex, Sun and HIV," The New York Amsterdam News, August 24-30, 2006, p. 2; Donna Hughes, Best Practices to Address the Demand Side of Sex Trafficking, U.S. Department of State, Office to Monitor and Combat Trafficking in Persons (August 2004), https://www.researchgate.net/publication/237564679_Best_Practices_to_Address_the_Demand_Side_of_Sex_Trafficking (accessed March 15, 2017); Melissa Farley, "Prostitution Harms Women Even If Indoors: Reply to Weitzer," Violence Against Women 11, no. 7 (July 2005): 950964; Mireya Navarro, "The West Gets Wilder," The New York Times, sec. 9, column 1, January 8, 2006, http://www.nytimes.com/2006/01/08/fashion/sundaystyles/the-west-gets-wilder.html (accessed March 13, 2017); Elizabeth Pisani et al., "HIV, Syphilis Infection, and Sexual Practices among Transgenders, Male Sex Workers, and Other Men Who Have Sex with Men in Jakarta, Indonesia," Sexually Transmitted Infections 80 (2004): 536-540.
} 
document the existence of such individuals on any scale has been impossible. 3

One's philosophical view of prostitution is at the crux of any discussion of the commercial sex trade. There are two primary views: 1) that prostitution exemplifies female equality with men, and the contrasting view, 2) that prostitution is a system of female inequality and male domination. Those subscribing to the first view are often described as sex work advocates. Those holding the second are often referred to as Radical Feminists or Abolitionists.

\section{Sex Work View}

The sex work view has three primary tenants: 1) that many women freely choose prostitution, 2) that prostitution should be viewed and respected as legitimate work, and 3) that it is a violation of a woman's civil rights to be denied the opportunity to support oneself as a "sex worker."4 This perspective accepts sex as a public commodity that can be purchased through contractual agreements for the exchange of sex acts in return for something of value.

Advocates of this view make a distinction between "free or voluntary" and "forced" prostitution. 5 In so doing, sex work advocates acknowledge that at least some prostitution may involve coercion, exploitation, or violence, but maintain that not all prostitution is inherently exploitive and that "choosing" to prostitute in a "non-coercive" context is the realization of a woman's sexual autonomy and agency. ${ }^{6}$

3 Vern Bullough and Bonnie Bullough, Women and Prostitution: A Social History, rev. ed. of Prostitution: An Illustrated Social History (USA: Prometheus Books, 1987), 291-292.

4 Lacey Sloan and Stephanie Wahab, "Feminist Voices on Sex Work: Implications for Social Work," AFFILIA 15, no. 4 (2000): 457-479; Valerie Jenness, "From Sex as Sin to Sex as Work: COYOTE and the Reorganization of Prostitution as a Social Problem," Social Problems 37, no. 3 (August 1990): 403-420.

5 Jenness, ibid; Bridget Anderson and Julia O'Connell Davidson, Trafficking-a Demand Led Problem? A Multi-Country Pilot Study (Save the Children Sweden, 2002), http://www.jagori.org/wpcontent/uploads/2006/03/The\%20Demand\%20Side.pdf (accessed March 12, 2017); Kathy Miriam, "Stopping the Traffic in Women: Power, Agency, and Abolition in Feminist Debates over SexTrafficking,” Journal of Social Philosophy 36, no. 1 (2005): 1-17.

${ }^{6}$ Annette Jolin, "On the Backs of Prostitutes: Feminist Theory and Prostitution Policy," Crime \& Delinquency 40, no. 1 (1994): 69-83. 


\section{Abolitionist}

In stark contrast, the Abolitionist view holds that human sexual relations devoid of intimacy, mutuality of pleasure, reciprocity of affection, and genuine consent are inherently dehumanizing. ${ }^{7}$ As the noted legal scholar Catherine MacKinnon has observed, this means that "Where sex is mutual, it is its own reward." Joe Parker puts it this way:

Real sexual relationships are not hard to find. There are plenty of adults of both sexes who are willing to have sex if someone treats them well, and asks. But there lies the problem. Some people do not want an equal, sharing relationship. They do not want to be nice. They do not want to ask. They like the power involved in buying a human being who can be made to do almost anything. 9

Rather than reflecting a mutual attraction, liking, affection, or concern for the other, "The sex purchased in prostitution is ingrained with narcissism, self-indulgence, and utilitarianism. It is drenched in predation. At its core, prostitution is about acquiring that which is not freely given."10 As Rachel Moran explains:

Prostitution and rape are commonly distinguished by the logical fact that to buy something and to steal something are two different things; but when we consider that the sex bought in prostitution is the same type of sex stolen in rape, sex that is, as Kathleen Barry puts it: '. . . disembodied, enacted on the bodies of women who, for the men, do not exist as human beings, and the men are always in control'-it is then that we understand how deeply traumatising it is for the woman whose body is so used. When we understand that the sex paid for in prostitution shares so many of its characteristics with the sex stolen in rape, it makes sense that so many prostituted women make clear parallels between the two experiences. One woman described her experience of the sex of prostitution very succinctly when she referred to it as: 'Paid rape.' Canadian campaigner Trisha Baptis, who was first prostituted as a child, describes it as 'pay-as-you-go rape.' Another woman described it as 'like signing a contract to be raped' and I

7 Julia O’Connell Davidson, Prostitution, Power and Freedom (Cambridge Polity Press, 1998): quoted in Grainne Healy and Monica O'Conner, "The Links between Prostitution and Sex Trafficking: A Briefing Handbook," Coalition against Trafficking Women and the European Women's Lobby joint project on Promoting Preventative Measures to Combat Trafficking in Human Beings for Sexual Exploitation: A Swedish and United States Governmental and Non-Governmental Partnership, 2006, http://www.catwinternational.org/Content/Images/Article/175/attachment.pdf (accessed March 17, 2017).

8 Catherine A. MacKinnon, “Trafficking, Prostitution, and Inequality," Harvard Civil Rights-Civil Liberties Law Review 46 (2011): 271-309.

9 Joe Parker, "How Prostitution Works," Prostitution Research and Education, http://www.prostitutionresearch.com/How\%20prostitution\%20works.pdf (accessed March 19, 2017).

${ }^{10}$ Lisa L. Thompson, “Does Legalizing Prostitution Prevent or Cause Harm?” in Finding Our Way through the Traffick: Navigating the Complexities of a Christian Response to Sexual Exploitation and Trafficking, eds. Christa Crawford and Glenn Miles, with Gundelina Velazco (Regum Books, 2017). 
wrote an article for the Irish Examiner in 2012 where I described prostitution as 'being raped for a living.'11

Paid sex acts, then, necessarily violate human dignity because such exchanges are devoid of the essential hallmarks of healthy sexual relationships. Additionally, because commercial sex depends on some type of financial inducement to coerce a sexual exchange, payment for sex is considered a form of sexual coercion and abuse.

Thus, other forms of commercial sex-pornography, stripping, webcamming, etc.-because they involve financial inducement to obtain sex acts are forms of prostitution, and ergo, forms sexual exploitation. Together the enterprises which purvey commercial sex to consumers constitute systems of organized ${ }^{12}$ sexual exploitation. Moreover, given that systems of organized sexual exploitation exist to cater to the fulfilment of male sexual wants, and that the majority of those used to satisfy those sexual wants are female, "the existence of prostitution presents a priori proof of women's inequality." 13 To Abolitionists, prostitution is ultimately the manifestation of men's choices and the male demand that women's bodies be sold as public sexual commodities. ${ }^{14}$

Irrespective of the degree to which a woman may be exercising her autonomy in choosing to prostitute, Abolitionists consider prostitution harmful, in part because the harmful effects of an experience are not mitigated by the fact that an individual may or may not have chosen the experience. As has been explained:

Harm is different. It is an objective condition, not a way of feeling; to be harmed is to have one's interests set back, to be made worse off, to have one's circumstances made worse than they were or than they would be in the absence of the thing that's doing the harm. Whether a person is harmed or not does not depend on how she feels .... That something is chosen or consensual is perfectly consistent with its being seriously oppressive, abusive, and harmful-to oneself and/or to a broader group of which one is a member (e.g. women). ${ }^{15}$

Consequently, this group does not utilize a prostitution taxonomy that creates classifications such as "voluntary" or "forced prostitution." Instead Abolitionists maintain that "Prostitution is ontologically a form of violence." 16 Therefore, the harm of prostitution is not restricted to the conditions by which it is carried out, but exists in the very carrying out of prostitution itself.

${ }^{11}$ Rachel Moran, Paid For: My Journey through Prostitution, (New York, NY: W. W. Norton \& Company Ltd., 2013).

${ }^{12}$ By “organized" I mean planned and controlled, frequently by powerful groups.

${ }^{13}$ Jolin, ibid.

${ }^{14}$ Miriam, ibid.

${ }^{15}$ Rebecca Whisnant, "Confronting Pornography: Some Conceptual Basics," in Not for Sale: Feminists Resisting Prostitution and Pornography, eds. Christine Stark and Rebecca Whisnant (Australia: Spinifex Press Pty Ltd, 2004), 22-23.

${ }^{16}$ Richard Poulin, "The Legalization of Prostitution and Its Impact on Trafficking in Women and Children,” (2005) https://sisyphe.org/spip.php?article1596 (accessed March 18, 2017). 
Adopting the Abolitionist perspective, the remainder of this paper frames the full spectrum of commercial sex enterprises as supplying persons for the purpose of sexual exploitation. The consumers of sex from the persons these enterprises sell for sexual purposes constitute "the demand."

\section{The Global Supply Chain of Organized Sexual Exploitation}

According to Investopedia, "A supply chain is a network between a company and its suppliers to produce and distribute a specific product, and the supply chain represents the steps it takes to get the product or service to the customer." 17 It is important to recognize that, "supply chains include every business that comes in contact with a particular product ...."18

The continuum of businesses comprising the commercial sex industry includes the following: pornography production and distribution enterprises, strip joints (including topless bars, as well as table and lap dancing), live-sex shows, peep shows, Internet-based (i.e., "virtual") prostitution, ${ }^{19}$ escort or outcall services, prostitution/sex tour operators, and brothels (frequently operating behind fronts such as massage parlors, saunas, bathhouses, bars, cabarets, clubs, cinemas, beauty salons, barber shops, and restaurants), as well as pimp-facilitated, streetlevel prostitution. ${ }^{20}$

Those profiting from this commerce in human beings sold for sex include not only those directly involved-such as sex traffickers (also referred to as pimps), strip club owners, brothel keepers, madams, and pornographers-but also a wide range of other parties such as the tourism industry, ${ }^{21}$ restaurant owners, taxi drivers, security firms, accountants, lawyers, doctors, advertisers, portions of the public health sector, Internet service providers, as well as local, regional, and national governments. So, while the entities that comprise the global organized sexual exploitation supply chain may appear to be limited to the small-time operators of back alley brothels, sleazy bars, and seedy red-light districts, when one considers

\footnotetext{
${ }^{17}$ Investopedia, “Supply Chain,” n.d., http://www.investopedia.com/terms/s/supplychain.asp (accessed March 18, 2017).

${ }^{18}$ Ibid.

19 Including forms of Internet-facilitated prostitution such as so-called "sugar daddy" websites.

${ }^{20}$ Laura María Agustín, "New Research Directions: The Cultural Study of Commercial Sex," Sexualities 8, no. 5 (2005): 618-631; Melissa Farley, Prostitution and Trafficking in Nevada: Making the Connections (San Francisco, CA: Prostitution Research \& Education, 2007); Sheila Jeffreys, "Globalizing Sexual Exploitation: Sex Tourism and the Traffic in Women," Leisure Studies 18 (1999): 179-196; Laxmi Murthy, "Goodbye Madame, Hello 'Sex Sector,'” Asia Times Online, July 29, 1999, http://www.atimes.com/se-asia/AG29Ae02.html (accessed March 17, 2017); Xin Ren, "Prostitution and Economic Modernization in China," Violence Against Women 5, no. 12 (1999): 1411-1436; Christine Stark and Carol Hodgson, "Sister Oppressions: A Comparison of Wife Battering and Prostitution," in Prostitution, Trafficking and Traumatic Stress, ed. Melissa Farley (Binghamton, NY: The Haworth Press, Inc., 2003), 17-32.; Celia Williamson and Terry Cluse-Tolar, "Pimp-Controlled Prostitution: Still an Integral Part of Street-Life," Violence Against Women 8, no. 9 (2002): 1074-1092; Jinghao Zhou, "Chinese Prostitution: Consequences and Solutions in the Post-Mao Era,” China: An International Journal 4, no. 2 (2006): 238-262.

${ }^{21}$ For instance, in Germany "Travel agencies offer tours to German brothels lasting up to eight days ... Prospective customers are promised up to 100 "totally nude women" wearing nothing by heels.” See Spiegel Online, "How Legalizing Prostitution Has Failed,” May 30, 2013, http://www.spiegel.de/international/germany/human-trafficking-persists-despite-legality-ofprostitution-in-germany-a-902533.html (accessed March 18, 2017).
} 
the wide range of financial beneficiaries in the aggregate, we find powerful multinational, multifaceted "sex sectors." 22 These sectors can be so substantial in size that they contribute significantly to the GDPs of national governments. ${ }^{23}$

Such industries, which often include both legal and illegal elements, exist around the world and are commonly referred to using innocuous terms such as the "sex trade," the "sex sector" and "commercial sex industry." However, what these entities really constitute is a global supply chain of organized sexual exploitation.

The essential and indispensable commodities in this industry are human beings-primarily females-whose bodies are sold for sex.

When viewed from a macro-economic perspective, prostitution has little to do with the decisions of individual women, and much to do with the commoditization and industrialization of female bodies to feed the male consumer demand for sex. The global network of enterprises constructed to meet this demand generates robust profits for those who own, manage, or work for businesses linked to these enterprises. For instance:

- A study analyzing the size and structure of the underground commercial sex economies (UCSE) of eight major cities, Atlanta, Dallas, Denver, Kansas City (MO), Miami, San Diego, Seattle, and Washington, DC, estimated that in 2007 the cash-based UCSE in these cities ranged from $\$ 39.9$ to $\$ 290$ million-\$975.3 million total (excluding Kansas City). ${ }^{24}$ The sex traffickers interviewed took in $\$ 5,000$ (Kansas City) to $\$ 33,000$ (Atlanta) per week. 25 The pricing per individual sex act ranged from as low as $\$ 5$ for street-based prostitution, $\$ 150-300$ per hour for Internet-facilitated prostitution, to as much as $\$ 1,000$ for escort prostitution. ${ }^{26}$

- A study of San Diego County's illicit sex economy in 2013 was estimated to have generated $\$ 810$ million dollars. ${ }^{27}$

- In 2007, the government of Spain reported that every day €50 million were spent on prostitution, or more than $€ 18$ billion per year. ${ }^{28}$

\footnotetext{
${ }^{22}$ Lin Lean Lim, “The Economic and Social Bases of Prostitution in Southeast Asia.” In The Sex Sector: The Economic and Social Bases of Prostitution in Southeast Asia, ed. Lin Lean Lim (Geneva: International Labour Office, 1998), 1-28.

23 Ibid.

24 Meredith Dank, et al., "Estimating the Size and Structure of the Underground Commercial Sex Economy in Eight Major US Cities," Urban Institute (2014), http://www.urban.org/sites/default/files/publication/22376/413047-estimating-the-size-and-structure-of-the-undergroundcommercial-sex-economy-in-eight-major-us-cities.pdf (accessed March 17, 2017). Note: This total does not include an estimate for Kansas City, which due to insufficient data was dropped from analysis.

25 Ibid.

${ }^{26}$ Ibid.

${ }^{27}$ Ami Carpenter and Jamie Gates, "The Nature and Extent of Gang Involvement in Sex Trafficking in San Diego County,” NIJ- 2012-R2-CX-0028, April 2016, https://www.ncjrs.gov/pdffiles1/nij/grants/249857.pdf (accessed March 18, 2017).

28 "Comisión Mixta de los Derechos de la Mujer y de la Igualdad de Oportunidades en las Cortes Generales, Informe de la Ponencia Sobre la Situación de la Prostitution en Espana (ES),” May 24, 2007, http://www.congreso.es/public_oficiales/L8/CORT/BOCG/A/CG_A379.PDF (accessed March 18, 2017).
} 
- In 2008, researchers estimated that the Dutch prostitution industry generated between $€ 400-600$ million. ${ }^{29}$

- In India, it is reported that there are 2.5 million women engaged in prostitution. In Mumbai it is estimated that more than 100,000 women are prostituted 365 days a year, averaging 6 sexual buyers a day at $\$ 2$ for each sex act. The red-light district, Dharavi, in Mumbai generates at least $\$ 400$ million in revenue annually. ${ }^{30}$

- The Paradise night club in La Jonquera, Spain, is touted as the largest brothel in Europe. The club, which measures more than 8,850 square feet and boasts 80 rooms with rates of $\$ 166$ per hour, is one of 11 so-called "macro-brothels" in this region of Spain. Approximately 1,800 prostituted women are available there. ${ }^{31}$

- Germany's decision to legalize prostitution has given rise to "flat-rate" brothels which allow sex buyers to have as much sex as they want with any of the women in the brothel for one price. When one such club opened, the management advertised, "Sex with all the women as long as you want, as often as you want and the way you want. Sex. Anal sex. Oral sex without a condom. Threeways. Group sex. Gang bangs.” Police reported that about 1,700 sex buyers participated on the opening weekend. As many as 700 men stood in line outside the brothel. Later, sex buyers complained in Internet forums that the women were no longer fit for use after a few hours. ${ }^{2}$

This supply chain of organized sexual exploitation exists to cater to and profit from one class of individual-male commercial sex buyers.

It takes a lot of $\$ 2, \$ 100, \$ 1000$ commercial sex purchases to fuel a system generating billions of dollars in income, supporting a myriad of stakeholders, and bolstering national economies. Behind each of those transactions is an individual, most likely a man, who has decided that he is entitled to have what he wants, when he wants it, irrespective of the consequences to others. 33

As the quotes below from sex buyers reveal, the extent of their sexual callousness and sense of sexual entitlement can be breathtakingly raw and inhuman.

- "Being with a prostitute is like having a cup of coffee, when you're done, you throw it out." 34

\footnotetext{
${ }^{29}$ Brugt Kazemier, et al., "The Contribution of Illegal Activities to National Income in the Netherlands," Statistics Netherlands, 2014.

$3^{\circ}$ Geetha Suresh, L. Allen Furr, and Aylur Kailasom Srikrishnan, "An Assessment of the Mental Health of Street-Based Sex Workers in Chennai, India," Journal of Contemporary Criminal Justice 25, no. 2 (2009): 186-201.

${ }^{31}$ Dale Fuchs, "Open for Business: The Brothel with 1,800 Prostitutes," Independent, October 22, 2010, http://www.independent.co.uk/news/world/europe/open-for-business-the-brothel-with1800-prostitutes-2114265.html (accessed March 19. 2017).

$3^{2}$ Spiegel Online, “How Legalizing Prostitution Has Failed,” May 30, 2013, http://www.spiegel.de/international/germany/human-trafficking-persists-despite-legality-of-prostitution-in-germany-a-902533-2.html (accessed March 19, 2017).

33 Parker, ibid.

34 Melissa Farley, "Comparing Sex Buyers with Men Who Do Not Buy Sex: New Data on Prostitution and Trafficking," Journal of Interpersonal Violence (August 2015).
} 
- "If my fiancée won’t give me anal, I know someone who will." 35

- "The whole thrill of it, prostitute hunting." 36

- "There are no boundaries."37

- "I usually call for a girl, you know, like a pizza." 38

- "Anything you can't get from your girlfriend or wife, you can get from a prostitute." 39

- "They will do anything you ask them for with no complaints and nothing said back.40 'Your wish is my command,' like a genie jumping out of a bottle."

- “... she gave up her rights when she accepted my money." 41

- "You don't care about this person-it's a feeling of no strings. I don't have to see that person anymore if I don't want to."42

- "Something at your job makes you mad, you can't beat your wife, you can't beat your kids, and so you go out and have sex to take your frustration out." 43

- "Regardless if you have sex with a woman who is a prostitute; women are all the same, they all make you pay. I see no difference in women as a whole." 44

- "Prostitution is like masturbating without having to use your hand."45

- "No big deal, it’s just like getting a beer." 46

- "It's like renting a girlfriend or a wife. You get to choose like a catalogue."47

- "It's like going to the toilet." 48

Thus, we see that the global supply chain of organized sexual exploitation is a system which industrializes sex and robs the sex act of love, equality, and reciprocity of pleasure. It is a system that consents to the daily, serial sexual exploitation of millions of people. To the degree that we ignore it, tolerate it, or participate in it,

35 Ibid.

${ }^{36}$ Ibid.

37 Ibid.

${ }^{38}$ Rachel Durchslag and Samir Goswami, "Deconstructing the Demand for Prostitution: Preliminary Insights from Interview with Chicago Men Who Purchase Sex," Chicago Alliance Against Sexual Exploitation (2008), http://www.slaverynomore.org/wp-content/uploads/2011/07/Deconstructing-the-Demand-for-Prostitution.pdf (accessed March 18, 2017).

39 Ibid.

40 Ibid.

${ }^{41}$ Ibid.

${ }^{2}$ Ibid.

43 Ibid.

44 Ibid.

45 Melissa Farley, Julie Bindel, and Jacqueline M. Golding, "Men Who Buy Sex: Who They Buy and What They Know," Eaves, London (December 2009), https://i1.cmsfiles.com/eaves/2012/04/MenWhoBuySex-89396b.pdf (accessed March 19, 2017).

46 Ibid.

47 Ibid.

${ }^{48}$ Emma Reynolds, “'I Clutched the Cash While He Used Me:' Former Prostitutes on Why They Want the Industry Banned," News.com.au, April 8, 2016, https://i1.cmsfiles.com/eaves/2012/04/MenWhoBuySex-89396b.pdf (accessed March 19, 2017). 
we concede to the daily sexual exploitation for the abused, addicted, homeless, impoverished, marginalized, widowed, abandoned, and orphaned.

\title{
The Plan for Combating Demand
}

For a comprehensive discussion of the strategies and policies needed to combat the demand for commercial sex, please see the report commissioned by Demand Abolition conducted by Abt Associates, "Developing a National Plan for Eliminating Sex Trafficking." 49 In addition to the array of items set forth there, I wish to call particular attention to the following recommendations from the National Center on Sexual Exploitation's "Freedom from Sexploitation Agenda."5o

1) Of all the initiatives the U.S. government could undertake, none would have as broad and as instantaneous an impact on diminishing the global supply chain of organized sexual exploitation worldwide than this:

\begin{abstract}
In furtherance of the Department of Defense's "2015 Combating Trafficking in Persons (CTIP) Instruction 2200.1," institute a rule making strip clubs off-limits to all U.S. military personnel worldwide. Strip clubs provide the perfect learning environment for sexually toxic attitudes and behaviors. Leering, jeering, sexual touching, lap dancing, acts of prostitution, sexual assaults, and sexual trafficking are everyday occurrences in strip clubs around the world. Military personnel participating in the consumption of commercial sex at strip clubs fuel the demand for sex trafficking. Moreover, military members cannot exploit and objectify women in one environment without it having a deleterious effect on other aspects of their lives, including their military service. ${ }^{51}$
\end{abstract}

2) Since the inception of the State Department's annual Trafficking in Persons Report, countries with legal regimes that normalize the demand for commercial sex have escaped receiving the lower tier ratings that such laws-which serve to further sexual trafficking-deserve. The following recommendation addresses this problem.

Pass H.R. 466, the "Sex Trafficking Demand Reduction Act." Specifically, this bill amends the Trafficking Victims Protection Act of 2000 regarding the determination of whether a government has made serious and sustained efforts to reduce the demand for commercial sex acts. Pursuant to the minimum standards for the elimination of sex trafficking, if a government has the authority to prohibit the purchase of commercial sex acts, but fails to do so, it shall be deemed a failure to make serious and sustained efforts to reduce the demand for commercial sex acts, irrespective of other efforts the government may have made.

\footnotetext{
49 Michael Shively, et al., "Developing a National Action Plan for Eliminating Sex Trafficking,” Abt Associates (2010), https://www.demandabolition.org/research-and-publications/developing-anational-action-plan-for-eliminating-sex-trafficking/ (accessed March 19, 2017).

$5^{\circ}$ National Center on Sexual Exploitation, "Freedom from Sexploitation Agenda," March 17, 2017, http://endsexualexploitation.org/wp-content/uploads/NCOSE_Freedom-from-SexploitationAgenda_Policy-Recommendations_03-17-2017.pdf (accessed March 19, 2017).

${ }^{51}$ Ibid.
} 
3) Established in 2002, National Security Presidential Directive-22 (NSPD-22)52 calls on the U.S. government to vigorously combat trafficking in persons. This policy framework incorporates efforts to combat the demand by calling on law enforcement to enforce "the law against all those who traffic in persons, including recruiters, transporters, harborers, buyers, and sellers ..." (emphasis added). Recommendations \#3a and \#3b below build on NSPD-22 and are particularly important as there is concern that some federal funding may be going to entities with policies on demand for commercial sex that contravene NSPD-22.

A) As the 2013 Trafficking in Persons Report observed, "If there were no demand for commercial sex, sex trafficking would not exist in the form it does today. This reality underscores the need for continued strong efforts to enact policies that prohibit paying for sex." Thus, it is imperative that DOJ, under the provisions of the Justice for Victims of Trafficking Act, prosecute those who "solicit or patronize" victims of human trafficking for the purpose of commercial sex acts. DOJ should also work with its federally funded anti-trafficking task forces to ensure the investigation, arrest, and prosecution of persons who purchase sexual acts, as part of a concerted effort to combat the demand for sex trafficking. DOJ must also work to ensure that its grantees support efforts to enforce state and local laws criminalizing the purchase of commercial sex, and reallocate and prioritize resources so that demand reduction efforts such as those undertaken in King County, Washington, and by Cook County Sheriff Tom Dart, are replicated across the country.

B) Direct the Departments of Justice, State, and Health and Human Services, as well as USAID, to provide guidance to U.S. states and foreign governments advising against the decriminalization of prostitution and against the normalization of prostitution as "sex work." Multilateral organizations such as the UN Women and UNAIDS, as well as organizations like Amnesty International and the Open Society Foundation, are pushing for the full decriminalization of prostitution in the U.S. and abroad. Full decriminalization of prostitution transforms pimps and sex traffickers into "business entrepreneurs," and institutes a de facto right for men to buy women, men, and children for sex. Such laws do not protect the human rights of persons in prostitution, but guarantee that their dehumanization and exploitation will continue.

4) Finally, efforts to reduce the demand for commercial sex that are successful may result in diminished livelihood for those currently involved in the sex trade. Accordingly, approaches to curtailing demand must be accompanied by funding for programs to provide training, resources, and case management assistance to those in the commercial sex trade wishing to find alternative livelihood opportunities.

\section{Conclusion}

Those who engage in buying sex hurt others and themselves. Their behavior contributes to staggering amounts of human suffering, fuels criminal enterprises, and is the reason the global supply chain of organized sexual exploitation exists.

${ }^{2}$ The White House, "National Security Presidential Directive/NSPD-22," http://www.combat-trafficking.army.mil/documents/policy/NSPD-22.pdf (accessed March 19, 2019). 
The damage they leave in their wake drains society of the valuable social, legal, and medical resources that must be extended in disparate attempts to heal those they have used and discarded like trash.

Moreover, when governments decriminalize or turn a blind eye to sex buying, they choose to allow the vulnerable, desperate, or reckless to become prey of the greedy, powerful, selfish, and lascivious. They choose to ensure that a pool of persons are always on supply as public sexual property. They choose to support the global supply chain of organized sexual exploitation.

Ironically, the debate about choice in prostitution is usually focused on those with the least power and control in the whole equation: the prostituting person. Those with the real power-sex buyers, pimps, corporate interests, and governments-are rarely, if ever, held accountable for their choices. Indeed, if sex buyers stopped choosing to buy sex today, the entire sex industry would disintegrate tomorrow.

Of course, no one is holding their breath waiting for that to happen. However, those who care about people in forms of organized sexual exploitation can choose to work collaboratively with prostitution survivors, social service providers, law enforcement, and policy makers, to shrink both the global supply chain of sexual exploitation by combating the demand. This is the only choice that fosters dignity, wholeness, vibrancy, and a world free from sexploitation.

\section{AUTHOR BIOGRAPHY}

Lisa Thompson, National Center on Sexual Exploitation

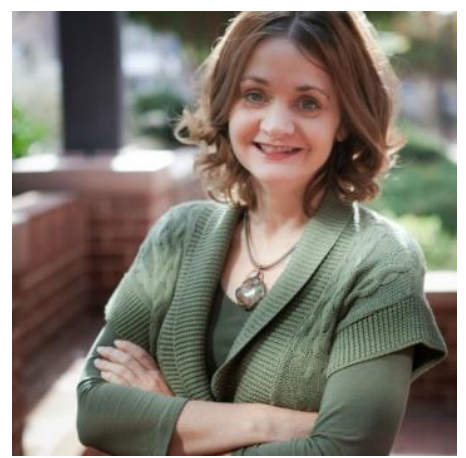

Lisa L. Thompson serves as the Vice President of Education and Outreach for the National Center on Sexual Exploitation, where she oversees NCOSE's strategic planning for increased public understanding of sexual exploitation related issues. She conducts analysis, develops research initiatives, and liaises with a wide range of public officials, non-profit organizations, institutions of higher learning, and academics to generate collaborative action to combat the full spectrum of sexual exploitation-especially as pertains to the harms of pornography, stripping, prostitution, and sexual trafficking. Lisa joins NCOSE following nearly two years with World Hope International (WHI), where as its Director of Anti-Trafficking, Lisa administered WHI's anti-trafficking and sexual violence recovery programs in Azerbaijan, Cambodia, Liberia and Sierra Leone. Lisa is a contributing author to Hands that Heal: International Curriculum for Caregivers of Trafficking Survivors, as well as the book Global Perspectives on Prostitution and Sex Trafficking: Europe Latin America, North America, and Global, in which she contributed chapters about the use of torture by pimps, as well as the policy conflicts between sex trafficking abolitionists and HIV/AIDS advocates. She has also provided expert testimony to the U.S. Congress. Additionally, Lisa served for more than 12 years as the Liaison for the Abolition of Sexual Trafficking for The Salvation Army USA National Headquarters. In that role, she pioneered strategies for The Salvation Army to create recovery services for survivors of sexual trafficking and advocated on public policy issues and initiatives related to combating sexual trafficking and other forms of commercial sexual exploitation. Lisa chaired The Salvation Army's North 
American Anti-Trafficking Council and directed its Initiative Against Sexual Trafficking. Lisa earned her Bachelor of Arts in Government from Western Kentucky University, and her Master's degree in Leadership, Public Policy and Social Issues from Union Institute and University.

\section{RECOMMENDED CITATION}

Thompson, Lisa L. The global supply chain of sexual exploitation and the necessity of combating the demand for commercial sex. Dignity: A Journal of Sexual Exploitation and Violence. Vol. 2, Issue 3, Article 8. DOI:10.23860/dignity.2017.02.03.08. Available at http://digitalcommons.uri.edu/dignity/vol2/iss3/08.

\section{REFERENCES}

Agustín, Laura María. "New Research Directions: The Cultural Study of Commercial Sex." Sexualities 8, no. 5 (2005): 618-631.

Anderson, Bridget, and Julia O'Connell Davidson. Trafficking-a Demand Led Problem? A Multi-Country Pilot Study. Save the Children Sweden, 2002. http://www.jagori.org/wpcontent/uploads/2006/03/The\%20Demand\%20Side.pdf.

Barry, Kathleen. The Prostitution of Sexuality. New York: New York University Press, 1995.

Bullough, Vern, and Bonnie Bullough. Women and Prostitution: A Social History, rev. ed. of Prostitution: An Illustrated Social History. USA: Prometheus Books, 1987.

Carpenter, Ami, and Jamie Gates. "The Nature and Extent of Gang Involvement in Sex Trafficking in San Diego County.” NIJ- 2012-R2-CX-0028, April 2016. https://www.ncjrs.gov/pdffiles1/nij/grants/249857.pdf.

“Comisión Mixta de los Derechos de la Mujer y de la Igualdad de Oportunidades en las Cortes Generales, Informe de la Ponencia Sobre la Situación de la Prostitution en Espana (ES).” May 24, 2007.

http://www.congreso.es/public_oficiales/L8/CORT/BOCG/

A/CG_A379.PDF

Cunningham, Jennifer. "Sex, Sun and HIV." The New York Amsterdam News, August 24-30, 2006.

Dank, Meredith, et al. "Estimating the Size and Structure of the Underground Commercial Sex Economy in Eight Major US Cities.” Urban Institute, 2014. http://www.urban.org/sites/default/files/publication/22376/413047estimating-the-size-and-structure-of-the-underground-commercial-sexeconomy-in-eight-major-us-cities.pdf.

Davidson, Julia O'Connell. Prostitution, Power and Freedom. Cambridge: Polity Press, 1998: quoted in Grainne Healy and Monica O'Conner, "The Links between Prostitution and Sex Trafficking: A Briefing Handbook." Coalition against Trafficking Women and the European Women's Lobby joint project on Promoting Preventative Measures to Combat Trafficking in Human Beings for Sexual Exploitation: A Swedish and United States Governmental and NonGovernmental Partnership, 2006.

http://www.catwinternational.org/Content/Images/Article/175/attachment.pdf. 
Durchslag, Rachel, and Samir Goswami. "Deconstructing the Demand for Prostitution: Preliminary Insights from Interview with Chicago Men Who Purchase Sex.” Chicago Alliance Against Sexual Exploitation, 2008. http://www.slaverynomore.org/wp-content/uploads/2011/07/Deconstructingthe-Demand-for-Prostitution.pdf.

Farley, Melissa. Prostitution and Trafficking in Nevada: Making the Connections. San Francisco: Prostitution Research \& Education, 2007.

- - . "Prostitution Harms Women Even If Indoors: Reply to Weitzer." Violence Against Women 11, no. 7 (July 2005): 950-964.

Farley, Melissa. Jacqueline M. Golding, Emily Smuchman Matthews, Neil M. Malamuth, and Laura Jarrett. "Comparing Sex Buyers with Men Who Do Not Buy Sex: New Data on Prostitution and Trafficking." Journal of Interpersonal Violence (August 2015).

Fuchs, Dale. "Open for Business: The Brothel with 1,800 Prostitutes." Independent, October 22, 2010. http://www.independent.co.uk/news/world/europe/open-forbusiness-the-brothel-with-1800-prostitutes-2114265.html.

Hughes, Donna. Best Practices to Address the Demand Side of Sex Trafficking. U.S. Department of State, Office to Monitor and Combat Trafficking in Persons, August 2004. https://www.researchgate.net/publication/237564679_Best_Practices_to_Addr ess_the_Demand_Side_of_Sex_Trafficking.

Investopedia. "Supply Chain." n.d., http://www.investopedia.com/terms/s/supplychain.asp.

Jeffreys, Sheila. "Globalizing Sexual Exploitation: Sex Tourism and the Traffic in Women." Leisure Studies 18 (1999): 179-196.

Jenness, Valerie. "From Sex as Sin to Sex as Work: COYOTE and the Reorganization of Prostitution as a Social Problem.” Social Problems 37, no. 3 (August 1990): 403420.

Jolin, Annette. "On the Backs of Prostitutes: Feminist Theory and Prostitution Policy." Crime \& Delinquency 40, no. 1 (1994): 69-83.

Kazemier, Brugt. Arjan Bruil, Annemieke van de Steeg, and Marieke Rensman. "The Contribution of Illegal Activities to National Income in the Netherlands.” Statistics Netherlands (2014).

Lim, Lin Lean. "The Economic and Social Bases of Prostitution in Southeast Asia." In The Sex Sector: The Economic and Social Bases of Prostitution in Southeast Asia. ed. Lin Lean Lim, 1-28. Geneva: International Labour Office, 1998.

MacKinnon, Catherine A. "Trafficking, Prostitution, and Inequality." Harvard Civil Rights-Civil Liberties Law Review 46 (2011): 271-309.

Miriam, Kathy. "Stopping the Traffic in Women: Power, Agency, and Abolition in Feminist Debates over Sex-Trafficking.” Journal of Social Philosophy 36, no. 1 (2005): 1-17.

Moran, Rachel. Paid For: My Journey through Prostitution. New York: W. W. Norton \& Company Ltd., 2013.

Murthy, Laxmi. “Goodbye Madame, Hello ‘Sex Sector.” Asia Times Online, July 29, 1999. http://www.atimes.com/se-asia/AG29Ae02.html.

Navarro, Mireya. “The West Gets Wilder.” The New York Times, sec. 9, column 1, January 8, 2006. http://www.nytimes.com/2006/01/08/fashion/sundaystyles/the-westgets-wilder.html.

Parker, Joe. "How Prostitution Works." Prostitution Research and Education. http://www.prostitutionresearch.com/How\%20prostitution\%20works.pdf. 
Pisani, Elizabeth, et al. "HIV, Syphilis Infection, and Sexual Practices among Transgenders, Male Sex Workers, and Other Men Who Have Sex with Men in Jakarta, Indonesia." Sexually Transmitted Infections 80 (2004): 536-540.

Poulin, Richard. "The Legalization of Prostitution and Its Impact on Trafficking in Women and Children.” 2005. https://sisyphe.org/spip.php?article1596.

Ren, Xin. "Prostitution and Economic Modernization in China." Violence Against Women 5, no. 12 (1999): 1411-1436.

Sloan, Lacey, and Stephanie Wahab. "Feminist Voices on Sex Work: Implications for Social Work." AFFILIA 15, no. 4 (2000): 457-47.

Spiegel Online. 2013. "How Legalizing Prostitution Has Failed.” May 30. http://www.spiegel.de/international/ germany/human-trafficking-persistsdespite-legality-of-prostitution-in-germany-a-902533-2.html.

Stark, Christine and Carol Hodgson. "Sister Oppressions: A Comparison of Wife Battering and Prostitution.” In Prostitution, Trafficking and Traumatic Stress. ed. Melissa Farley, 17-32. Binghamton: The Haworth Press, Inc., 2003.

Suresh, Geetha, L. Allen Furr, and Aylur Kailasom Srikrishnan. "An Assessment of the Mental Health of Street-Based Sex Workers in Chennai, India." Journal of Contemporary Criminal Justice 25, no. 2 (2009): 186-201.

Thompson, Lisa L. "Does Legalizing Prostitution Prevent or Cause Harm?” In Finding Our Way through the Traffick: Navigating the Complexities of a Christian Response to Sexual Exploitation and Trafficking, edited by Christa Crawford and Glenn Miles, with Gundelina Velazco. Regum Books, 2017.

Whisnant, Rebecca. “Confronting Pornography: Some Conceptual Basics.” In Not for Sale: Feminists Resisting Prostitution and Pornography, edited by Christine Stark and Rebecca Whisnant, 22-23. Australia: Spinifex Press Pty Ltd, 2004.

The White House. "National Security Presidential Directive/NSPD-22." http://www.combat-trafficking.army.mil/documents/policy/NSPD-22.pdf.

Williamson, Celia and Terry Cluse-Tolar. "Pimp-Controlled Prostitution: Still an Integral Part of Street-Life." Violence Against Women 8, no. 9 (2002): 1074-1092.

Zhou, Jinghao. "Chinese Prostitution: Consequences and Solutions in the Post-Mao Era." China: An International Journal 4, no. 2 (2006): 238-262. 